\title{
PEMBELAJARAN PENDIDIKAN AGAMA ISLAM (PAI) BERBASIS AKTIVITAS KONTEKSTUAL DI MI ALAM ALFA KIDS PATI
}

\author{
Abu Choir \\ IAIN Kudus, Kudus, Indonesia \\ abuchoir.smg@gmail.com
}

\begin{abstract}
Abstrak
Penelitian ini bertujuan untuk menemukan dan mendeskripsikan proses pembelajaran Pendidikan Agama Islam (PAI) berbasis aktivitas kontekstual yang dilakukan di MI Alam Alfa Kids Pati. Penelitian ini meggunakan jenis penelitian kualitatif deskriptif dengan pendekatan partisipatif. Teknik pengumpulan data dengan menggunakan wawancara mendalam, observasi partisipatif, dan penkajian dokumen. Sementara analisis data digunakan model analisis interaktif meliputi reduksi data, penyampaian data, dan penarikan kesimpulan. Berdasarkan hasil dan pembahasan penelitian bahwa pembelajaran PAI berbasis aktivitas kontekstual adalah pembelajaran PAI rekonstruktif kontekstualis, yakni upaya kreatif dalam pembelajaran PAI untuk mendekatkannya dengan kehidupan yang nyata, sehingga PAI menjadi aplikatif dan implementatif sesuai dengan tuntutan kehidupan. Untuk mencapai hal ini diperlukan pemahaman tentang hal-hal sebagai berikut: 1) Pemahaman makna PAI berbasis aktivitas yang rekonstruktif kontektualis; 2) Kemampuan memilih jenis aktivitas yang rekonstruktif kontektualis; 3) Daur proses pendidikan yang rekonstruktif kontektualis.
\end{abstract}

Kata Kunci: Pembelajaran, PAI, Kontekstual

\begin{abstract}
Abstrack
This study aims to find and describe the learning process of Islamic Religious Education (PAI) based on contextual activities carried out at MI Alam Alfa Kids Pati. This study uses a type of descriptive qualitative research with a participatory approach. Data collection techniques using in-depth interviews, participatory observation, and document review. While data analysis used an interactive analysis model including data reduction, data delivery, and conclusion drawing. Based on the results and discussion of the study that PAI learning based on contextual activity is the learning of PAI contextualist reconstructive, namely the creative effort in PAI learning to bring it closer to real life, so that PAI becomes applicable and implementative in accordance with life's demands. To achieve this, an understanding of the following matters is needed: 1) Understanding the meaning of PAI-based activities that are reconstructive contextualists; 2) The ability to choose the types of activities that are reconstructive contextualists; 3 ) The process of recycling a reconstructive contextual education process.
\end{abstract} Keywords: Learning, PAI, Contextual 


\section{A. Pendahuluan}

Pendidikan agama Islam (PAI) saat ini masih menuai berbagai kritik yang tajam, karena dianggap belum mampu menanggulangi berbagai isu penting di masyarakat. Persoalan korupsi, intoleransi, tindakan kriminal dan kekerasan, bahkan pergaulan sex bebas di kalangan pelajar dianggap sebagai indikator bahwa pendidikan agama Islam belum sesuai harapan. Sekalipun tentu tidak adil, jika semua problema tersebut dibebankan kepada PAI di sekolah, karena pembentukan kepribadian siswa di sekolah tidak hanya oleh PAI saja, namun hal ini juga dapat dijadikan pemahaman bahwa masyarakat memang sangat berharap kepada PAI ini.

Persoalan fenomena untuk menghidupkan pendidikan Islam sebenarnya telah dikemukakan oleh para intelektual muslim. Fazlur Rahman misalnya, melalui buku yang berjudul Islam and Modernity, Transformation of an Intellectual Tradition semula berjudul Education and Modernity (Pendidikan Islam dan Modernitas) berusaha menghidupkan pendidikan. Konsep pendidikan yang menghidupkan, yaitu pendidikan yang diselenggarakan secara integratif untuk mengatasi persoalan-persoalan yang dihadapi oleh umat manusia (Sutrisno, 2008).

Menurut Fazlur Rahman, bahwa kelemahan sistem pendidikan umat Islam, karena diselenggarakan secara dualisme, yaitu sistem pendidikan tradisional (Islam) pada satu sisi dan sistem pendidikan sekuler modern (umum) pada sisi lain. Fazlur Rahman berusaha mengintegrasikan kedua sistem pendidikan tersebut, sebagai solusi atas persoalan dualisme sistem pendidikan umat Islam. Solusi ini dianggap sebagai menghidupkan pendidikan Islam (Sutrisno, 2008).

Integrasi kelembagaan semacam ini diharapkan dapat mengembalikan pendidikan umat Islam untuk dapat melahirkan kembali tokoh-tokoh intelektual muslim seperti Ibn Khaldun, Ibn Sina, Al Ghozali, dan lain sebagainya. Namun integrasi kelembagaan semacam ini-sekalipun mulai dikembangkan pada beberapa UIN-belum dapat menunjukkan hasil memuaskan.

Integrasi ini masih menyisakan persoalan-persoalan baru dalam dataran implementasi di lapangan. Persoalan integrasi kelembagan, baru berhasil pada 
ranah Pendidikan Tinggi, belum menyentuh pada pendidikan dasar dan menengah. Padahal pada pendidikan dasar dan menengah merupakan ciri pendidikan suatu bangsa. Disamping itu perubahan IAIN menjadi UIN, masih menyisakan kekhawatiran beberapa pihak akan hilangnya ruh kajian keagamaan Islam. Hal demikian sebagaimana dinyatakan oleh M. Nuh Menteri Pendidikan dan Kebudayaan era pemerintahan Presiden Susilo Bambang Yudoyono, bahwa yang penting harus dijaga itu adalah ada kecenderungan kalau jadi UIN itu akarnya (ilmu-ilmu keagamaan) ditinggal, yang umumnya seperti Fakultas Kedokteran dan Tekniknya yang didorong maju. Terus nanti siapa yang mengurusi agamanya, diserahkan ke siapa, itu yang menjadi masalah. (Liputan 6, 23 Juli 2013, Jam 15.39 WIB, Mendikbud: IAIN Berubah Jadi UIN, Siapa yang Urus Agama?). Namun menurut Ahmad Tafsir perubahan IAIN menjadi UIN justru diperlukan karena beberapa alasan seperti: (1) kita memerlukan pemikir yang mampu berpikir komprehensif; (2) ilmu agama memerlukan ilmu umum; (3) meningkatkan harga diri sarjana dan mahasiswa muslim; (4) menghilangkan paham dikotomik agama-umum; (5) memenuhi harapan masyarakat muslim; (6) memenuhi kebutuhan lapangan kerja; dan (7) berkehendak untuk memenuhi harapan umat Islam dengan memberi mereka kedudukan yang lebih penting dalam pendidikan nasional (Ahmad Tafsir). Padahal integrasi ini sejatinya dimaksudkan untuk menjadikan pendidikan Islam menjadi suatu organisme yang utuh sebagai kesatuan, sehingga dapat berperan banyak dalam persoalan kemanusiaan, bukan terpisah-pisah atas dikotomi ilmu dan juga bukan sekedar mekanisme diantara ilmu-ilmu yang lain. Menurut Muhaimin beberapa paradigma pengembangan pendidikan Islam yang ada sampai dengan saat ini dicirikan pada tiga bentuk, yaitu: 1) paradigm formism, yang cenderung dikotomik; 2) paradigma mechanism, yang bekerja sendiri-sendiri hanya saling mempengaruhi seperti mesin; dan 3) paradigma organism, yang lebih terintegrasi dalam suatu sistem yang utuh. (Muhaimin, 1998, : 6-10).

Lain daripada itu, upaya menghidupkan agama Islam juga dapat dilakukan dengan inovasi kreatif pada proses pembelajaran. Inovasi ini memungkinkan dilakukan setiap guru dan kepala madrasah agar dapat mendekatkan antara teori dan praktik. Hal demikian diantarnya karena 
seringkali terjadi kesenjangan antara kemampuan kognitif peseta didik dengan sikap dan praktik keagamaannya. Peserta didik mampu menjawab dengan benar berbagai soal tes kognitif yang diberikan guru, namun dalam ranah sikap dan perilaku masih jauh dari harapan. Inovasi kreatif yang menyentuh langsung pada proses pembelajaran akan mungkin dijalankan oleh guru dan pemegang kebijakan terdepan di madrasah.

Guru sebagai pemimpin instruksional akan dapat menjadikan proses belajar mengajarnya lebih kreatif dan menarik, sehingga membuat siswa lebih tertarik mengikuti proses dan mendapatkan hasil pembelajaran yang komprehensif sesuai dengan tujuan pembelajaran. Sedangkan kepala madrasah sebagai pemimpin institusional dapat mengkreasikan sejumlah kebijakan yang menjadikan suasana madrasah mendukung terjadinya proses tersebut. Tentu saja untuk dapat melakukan inovasi kreatif demikian, seorang guru dan kepala madrasah harus mampu: 1) menguasai materi agama Islam yang koprehensif serta wawasan dan bahan penghayatan, terutama pada bidang yang menjadi tugasnya; 2) mengusai strategi (mencakup pendekatan, metode, dan teknik) pendidikan Islam, termasuk kemapuan evaluasinya; 3) menguasai ilmu dan wawasan kependidikan; 4) memahami prinsip-prinsip dan menafsirkan hasil penelitian pendidikan pada umumnya guna keperluan pengembangan pendidikan Islam; dan 5) memiliki kepekaan informasi secara langsung yang mendukung kepentingan tugasnya (Muhaimin dan Abdul Mudjieb, 1993:172).

Beberapa kajian telah menunjukkan, bahwa inovasi kreatif demikian dapat mengatasi beberapa problema pembelajaran PAI di sekolah, seperti keterbatasan jam pelajaran dan dana. Minnah El Widdah dalam jurnal At Ta'lim Vo. 4 Tahun 2013, misalnya, menawarkan inovasi kreatif dalam pembelajaran PAI di SMP, melalui: 1) menyelenggarakan Bina Rohani Islam (Rohis); 2) Mengondisikan Sekolah dengan Kegiatan Keagamaan (islamisasi sekolah); 3) Menggunakan metode insersi (sisipan) dalam proses pembelajaran (Minnah El Widdah, 2013 : 88-90). Sementara itu Hari Priatna Sanusi lebih pada penciptaan nuansa religius di sekolah, seperti 1) menebarkan salam kepada siswa dan guru; 2) pelaksanaan sholat jamaah di 
sekolah; 3) pengajian dan baca tulis al Quran; 4) praktek ibadah; dan 5) kegiatan silaturrahim di kalangan siswa ( Hary Priatna Sanusi, 2013 : 150).

Namun inovasi ini masih terbatas pada nuansa kelas dengan suasana lingkungan dan sumber terbatas, sehingga cenderung bersifat manipulasi dan tidak nyata karena dalam lingkungan yang imitasi. Berbeda dengan hal tersebut di atas, inovasi kreatif pembelajaran PAI yang dilakukan oleh MI Alam Alfa Kids Desa Ngablak Kecamatan Cluwak Kabupaten Pati lebih diarahkan pada mendekatkan pembelajaran PAI pada aktivitas kontekstual. Pembelajaran PAI di madrasah ini dikembangkan dalam suasana lebih relaks, dengan berbagai variasi proses yang menyenangkan, dan memberi kesempatan anak untuk terlibat langsung dalam proses pembelajaran pada lingkungan yang sebenarnya atau dikreasikan dalam simulasi proses sedemikian rupa sehingga mirip dengan kondisi sebenarnya. Melalui pembelajaran semacam ini pembelajaran PAI lebih menyenangkan dan terintegrasi dalam kehidupan siswa. Dalam pembelajaran tersebut, Peserta didik dapat terlibat dalam aktivitas yang menyentuh sikap spiritual, sosial, kognitif, dan psikomotorik. Pendidik juga lebih kreatif karena berfungsi sebagai fasilitator.

Strategi pembelajaran PAI seperti tersebut di atas, tentu saja membawa harapan positif bagi alternatif solusi terhadap problematika pembelajaran PAI di madrasah dan sekolah selama ini. Pembelajaran PAI yang terkesan monoton dan kaku. Sebagian guru berasumsi karena pembelajaran PAI sarat nilai sehingga diajarkan dengan cara yang monoton dan kaku. Tidak saja dalam strategi pembelajaran yang dipilih sangat terbatas, bahkan seringkali pembelajaran PAI disetting sedemikian rupa menjadi tidak menyenangkan karena sarat hafalan, indoktrinasi, dan miskin dialog, baik dalam ranah konsep maupun dengan kehidupan nyata. Selama ini dapat mencair dalam suasana gembira. Interaksi guru dan siswa dikembangkan dalam nuansa keakraban.

Berdasarkan hal tersebut di atas, penelitian ini diarahkan untuk menemukan dan mendeskripsikan inovasi kreatif pembelajaran PAI berbasis aktivitas kontekstual yang dilakukan MI Alam Alfa Kids. 


\section{B. Pembahasan}

\section{Pengertian Pendidikan Agama Islam Berbasis Aktivitas Langsung di MI Alam Alfa Kids}

Pendidikan Agama Islam berbasis aktivitas langsung di MI Alam Alfa Kids ialah upaya kreatif untuk mengembangkan variasi proses pembelajaran PAI agar dapat memberikan kesempatan peserta didik memperoleh sejumlah pengalaman belajar secara langsung (real learning), bermakna (meaning full) dan konstruktif. Pembelajaran demikian, mengutamakan pemberian pengalaman secara langsung kepada peserta terhadap praktik-praktik keagamaan melalui lingkungan terdekatnya, sehingga melalui pembelajaran ini akan tumbuh keaktifan peserta didik dalam mengamati, menyelediki serta mempelajari lingkungan.

Kondisi lingkungan yang sesungguhnya juga akan menarik perhatian spontan anak didik sehingga anak memiliki pemahaman dan kekayaan pengetahuan yang bersumber dari lingkungannya sendiri. Bahan-bahan pengajaran yang ada pada lingkungan sekitar anak akan mudah diingat, dilihat dan dipraktikan sehingga kegiatan pembelajaran menjadi berfungsi secara praktis.

Menurut Ibu Rubiah, S.Psi., filosofis pembelajaran yang berbasis lingkungan alam semacam ini, sebenarnya digagas pertama kali oleh Jan Lightghart pada tahun 1859 (Jan Lightart 11 Januari 1859-16 Februari 1916) merupakan tokoh pendidikan yang berupaya untuk menghasilkan manusia yang memiliki budi pekerti yang luhur, bukan hanya cerdas dan terdidik otaknya saja. Ia sangat menentang hukuman (terutama hukuman fisik) sebagai alat pendidikan. Dalam mendidik siswanya, Lightart banyak menggunakan bentuk pengajaran. Tokoh ini menyajikan suatu bentuk model pendidikan yang dikenal dengan "pengajaran barang sesungguhnya”. Konsep ini menjadi salah satu akar munculnya konsep pendidikan yang berbasis pada alam atau back to nature school. Ide dasarnya adalah pendidikan pada anak dilakukan dengan mengajak anak dalam suasana sesungguhnya melalui belajar pada lingkungan alam sekitar 
yang nyata. Bentuk pengajaran ini dilakukan sebagai upaya menentang bentuk pengajaran yang cenderung intelektualisme dan verbalistik.

Dalam konteks pendidikan Islam, pembelajaran praktik langsung ini mirip dengan pembelajaran yang dilakukan para guru-guru sufi kepada murid-muridnya. Para Guru Sufi melakukan kontemplasi dan latihan-latihan spiritual secara individual maupun kolektif dengan kurikulum yang khusus dirancang berbasis perbedaan individu sedemikian rupa agar setiap murid dapat mencapai derajat hasil sesuai tujuan yang telah ditetapkan. Dalam pendidikan tasawuf (tarikat), murid-murid yang disebut Salik tidak hanya diajarkan secara verbal, tetapi juga diajak disentuh hatinya, bahkan diajak melakukan perjalanan spiritual melalui berbagai aktivitas langsung ke lapangan untuk menemukan pengalaman langsung dari setiap peristiwa atau lingkungan tertentu. Para guru sufi mengajarkan secara personal dan kelompok kepada murid-murid tersebut dalam khanaqah, ribath, zawiyah, dan thariqah. Khanaqah, ribath, zawiyah, dan thariqah merupakan bentukbentuk institusi pendidikan di kalangan sufi yang biasanya dipimpin oleh para Syaikh atau Mursyid (Syamsun Niam, 2013).

Lingkungan alam merupakan salah satu komponen terpenting dalam pengembangan tujuan, isi dan proses pendidikan agama Islam berbasis aktivitas langsung tersebut. Lingkungan dalam hal ini memiliki konotasi pemahaman yang luas mencakup segala sumber yang ada dalam lingkungan anak (termasuk dirinya sendiri), lingkungan keluarga dan rumah, tetangga (tetangga pedagang, tetangga dokter, tetangga ulama (tokoh agama) dan tokoh masyarakat, tetangga peternak, dan tetangga petani), lingkungan yang berwujud makanan, minuman serta pakaian, gedung atau bangunan, kebun, persawahan dan lain-lain.

Melalui bentuk pembelajaran berbasis aktivitas langsung tersebut ini akan tumbuh keaktifan anak dalam mengamati, menyelediki serta mempelajari lingkungan sekitarnya. Kondisi lingkungan yang sesungguhnya juga akan menarik perhatian spontan anak sehingga anak memiliki pemahaman dan kekayaan pengetahuan yang bersumber dari lingkungannya sendiri. Bahan-bahan pengajaran yang ada pada lingkungan sekitar 
anak akan mudah diingat, dilihat dan dipraktikan sehingga kegiatan pengajaran menjadi berfungsi secara praktis.

MI Alam Alfa Kids mengunakan berbagai aktivitas keagamaan sebagai lingkungan untuk mengajarkan pendidikan agama Islam. Lingkungan tersebut dikreasikan dari berbagai: 1) upacara-upacara keagamaan, seperti maulud Nabi, 2) moment special keagamaan, seperti santunan yatim piatu, 3) tradisi-tradisi keagamaan, seperti kunjungan kepada calon jamaah haji dan jamaah haji yang baru pulang, halal bi halal, dan 4) praktik kegiatan ibadah, seperti sholat jamaah, manasik haji, kurban, zakat fitrah dan lain sebagainya.

Aktivitas-aktivitas keagamaan tersebut dijadikan pintu masuk untuk memberikan berbagai muatan kurikulum sesuai dengan Standar Kelulusan (SKL) yang telah ditetapkan pemerintah. Aktivitas keagamaan ini dirancang untuk menghidupkan pendidikan secara kontekstual dalam pembelajaran praktik langsung, sehingga anak dapat menguasai berbagai muatan Matematika, IPS, IPA, SBDP, PPKN, dan Agama Islam dengan suasana natural. Tentu saja pemilihan aktivitas tersebut tidak dilakukan sembarang, tetapi dirapatkan bersama antara pihak guru dan manajemen madrasah pada awal semester agar aktivitas tersebut benar-benar dapat menjadi pintu masuk untuk menjadikan agama sebagai kehidupan peserta didik.

\section{Jenis Aktivitas Pembelajaran Langsung pada Pendidikan Agama Islam di MI Alam Alfa Kids}

MI Alam Alfa Kids mengunakan berbagai aktivitas keagamaan sebagai lingkungan untuk mengajarkan pendidikan agama Islam. Lingkungan tersebut dikreasikan dari berbagai aktivitas seperti: 1) upacara-upacara keagamaan, seperti maulud Nabi, 2) moment special keagamaan, seperti santunan yatim piatu, 3) tradisi-tradisi keagamaan, seperti kunjungan kepada calon jamaah haji dan jamaah haji yang baru pulang, halal bi halal, dan 4) praktik kegiatan ibadah, seperti sholat jamaah, manasik haji, kurban, zakat fitrah dan lain sebagainya. Bahkan aktivitas-aktivitas keagamaan tersebut dijadikan pintu masuk untuk 
memberikan berbagai muatan kurikulum sesuai dengan Standar Kelulusan (SKL) yang telah ditetapkan pemerintah dalam buku kurikulum.

Aktivitas keagamaan tersbut dirancang untuk menghidupkan pendidikan secara kontekstual dalam pembelajaran praktik langsung, sehingga anak dapat menguasai berbagai muatan Matematika, IPS, IPA, SBdP, PPKN, dan Agama Islam dengan suasana natural. Pemilihan aktivitas tersebut tidak dilakukan sembarang, tetapi dirapatkan bersama antara pihak guru dan manajemen madrasah pada awal semester agar aktivitas tersebut benar-benar dapat menjadi pintu masuk untuk menjadikan agama sebagai kehidupan peserta didik. Adapun jenis-jenis aktivitas keagamaan telah digunakan oleh MI Alam Alfa Kids dalam pembelajaran adalah sebagai berikut:

\section{a. Berwudhu dan Sholat}

Setiap hari anak didik diajak melakukan aktivitas wudhu dan sholat. Aktivitas ini dilakukan saat memulai awal pembelajaran setiap hari dimana anak didik dibiasakan berwudhu dan sholat Dhuha dengan bimbingan guru. Selain itu anak didik juga melakukan aktivitas wudhu dan sholat ketika Dhuhur dan Ashar.

Seluruh rangkaian aktivitas keagamaan wudhu dan sholat lebih diarahkan untuk mencapai kompetensi tentang wudhu dan sholat sebagai kompetensi dasar seorang muslim. Dalam wudhu anak didik diarahkan mencapai kompetensi, seperti niat Wudhu, praktik pelaksanaan wudhu sesuai syara', dan doa setelah wudhu. Begitu juga kompetensi di bidang sholat, yaitu: niat sholat, bacaan rukun quoli/ucapan (takbir, s. al fatihah, tasyahud, dan salam) dan doa-doa dalam sholat, praktik sholat sesuai tuntunan syara', dan kebersamaan dalam sholat jamaah.

Penerapan aktivitas wudhu dan sholat ini sebagaimana dilihat saat observasi di kelas 1 dan 2 MI Alam Alfa Kids dilakukan dengan melakukan praktik wudhu dan sholat dengan membaca keras (jahr) semua bacaan niat, rukun qouli dan doa, sehingga semua anak terlibat dalam aktivitas. Sedangkan untuk kelas 3 sudah mulai diajarkan 
dengan suara pelan (siriyah) pada tempat dimana harus pelan dan keras dimana harus keras.

Menurut Ibu Hj. Rubiah, S.Psi. penerapan pembacaan keras dimaksudkan untuk membenarkan bacaan anak dan memudahkan anak menghafal dengan tanpa menghafal. Melalui praktik aktivitas wudhu dan sholat ini anak-anak kelas 1 mampu menghafal semua rukun qouli, niat dan doa-doa dalam wudhu dan sholat dalam 6 bulan pertama sekolah.

\section{b. Berhaji}

Berhaji adalah aktivitas keagamaan yang ditetapkan untuk merespon tradisi keagamaan di masyarakat. Berhaji bukan berarti mengajak anak didik melakukan ibadah sesungguhnya, namun aktivitas ini lebih digunakan untuk mengenal tradisi-tradisi keagaaman yang mengiringi ibadah haji di Indonesia. Aktivitas berhaji dilakukan dengan 1) mengunjungi/ziarah rumah calon jamaah haji; 2) manasik haji bersama; 3) membagi daging korban; dan 4) mengunjungi rumah jamaah haji yang kembali ke tanah air.

Semua aktivitas dengan sifat kekhasannya digunakan untuk mencapai muatan kurikulum Matematika, IPA, Bahasa Indonesia, SBdP, Fiqh, Aqidah Akhlak, dan muatan kurikulum lainnya. Seperti pada mengunjungi rumah calon jamaah haji saat sebelum dan sesudah pulang haji anak didik anak diajarkan tatakrama bertamu, berdoa untuk calon jamaah haji, dan membikin prakarya bingkai ucapan selamat menjalankan ibadah haji. Sedangkan dalam manasik haji disampaing muatan fiqh tentang haji anak didik dikenalkan muatan 1) matematika tentang diameter, jenis bangun dan ruang, dan ukuran tidak baku; 2) PPKN dan IPS tentang tertib aturan dan bekerjasama. Sementara dalam membagi daging kurban anak-anak belajar menimbang dalam matematika, makhluk hidup dalam IPA, dan menyantuni si papa sebagai bagian kepedulian sosial. 


\section{c. Berzakat fitrah}

Berzakat fitrah merupakan aktivitas keagamaan yang ditetapkan untuk mempraktikan agama sebagai suatu kewajiban secara personal. Zakat fitrah rukun Islam yang wajib bagi setiap individu muslim yang pada malam Id mempunyai kecukupan, sekalipun demikian zakat ini juga boleh diawalkan atau ta'jil. Sebagai bagian memberi layanan kepada peserta didik, zakat fitrah sekaligus dijadikan media pembelajaran.

Dalam berzakat fitrah anak didik diarahkan belajar muatan tentang siapa saja yang wajib zakat, berapa ukurannya, dan kepada siapa zakat itu didistribusikan dalam muatan fiqh. Peserta didik belajar membuat peta fakir miskin di sekitar sekolah dalam hal IPS dan menimbang ukuran zakat dalam muatan matematika.

\section{d. Menyantuni Anak Yatim}

Aktivitas menyantuni anak yatim adalah aktivitas keagamaan yang ditetapkan untuk merespon moment spesial keagamaan di masyarakat. Aktivitas ini biasanya dilakukan pada bulan muharam dimana marak aktivitas santunan yatim piatu di masyarakat.

Anak-anak diajak melakukan santunan yatim setelah sebelumnya dikemas dalam pembelajaran yang bervariasi di madrasah, seperti pembelajaran keluarga, testimoni yatim, dan membuat kado.

Melalui aktivitas santunan yatim ini peserta didik diajarkan tentang menghargai keluarga yang mereka miliki. Mereka juga diajarkan tentang silsilah keluarga dan pentingnya saling meyayangi di keluarga.

3. Daur Proses Pembelajaran Agama Berbasis Aktivitas Langsung di MI Alam Alfa Kids

MI Alam Alfa Kids menyadari pentingnya pendidikan untuk hidup ini, sehingga seluruh aktivitas pendidikan diarahkan untuk mengenalkan berbagai sendi kehidupan melalui praktik langsung. Seluruh kegiatan juga melibatkan multi inderawi yang menjadikan anak terlibat secara emosi, kreativitas, imajinasi, dan pengetahuannya. Anak-anak menjadi gembira dalam belajar dan disaat yang sama mereka belajar agama, pengetahuan, dan lingkungan hidup. 
Pembelajaran berbasis aktivitas langsung demikian, terus dilakukan di MI Alam Alfa Kids di Madrasah. Seperti ketika berzakat fitrah, anak-anak diajak mengenal langsung kewajiban zakat tersebut melalui akktivitas berzakat sejak dari niat, menimbang beras, membungkus, memilih mustahiq (yang berhak menerima zakat), membuat peta distribusi zakat sampai dengan mendistrubiskan langsung kepada yang berhak tersebut. Hal yang sama untuk aktivitas berwudhu, sholat, Tertib Berlalu Lintas, dan lain sebagainya. Dengan melakukan sendiri anak akan menguasai kemampuan yang diharapkan dan kemampuan tersebut akan bersifat longthem memory. Melalui pembelajaran kontektual demikian suasana belajar lebih hidup dan interaksi guru-murid lebih akrab.

Mengacu pada proses pembelajaran PAI berbasis aktivitas kontekstual tersebut, MI Alam Alfa Kids merancang daur proses pembelajaran agar dapat efektif dan efesien mencapai tujuan pembelajaran yang telah ditetapkan sebagai berikut:

a. Menentukan aktivitas pembelajaran yang menjadi pusat minat peserta didik;

Pusat minat peserta didik ditentukan berdasarkan bahan-bahan pengajaran yang terdapat pada lingkungan di sekitar anak, baik dari tema, peristiwa keagamaan, yang bisa dijadikan pijakan aktivitas pembelajaran. Penentuan pusat ini ditentukan berdasarkan lingkungan yang paling dekat dengan diri peserta ddidik itu sendiri, lingkungan terdekatnya kemudian berangsung-angsur ke lingkungan yang terjauh.

Pada saat bulan Muharram aktivitas yang dipilih MI Alam Alfa Kids ialah menyantuni yatim piatu. Hal demikian karena lingkungan masyarakat di sekitar peserta didik sedang ramai dengan kegiatan santunan anak yatim piatu. Aktivitas ini dipilih karena pihak sekolah menyadari, bahwa pada saat itu peserta didik secara emosi dan fisik terlibat dalam keramaian kegiatan santunan yatim piatu di masyarakat. Pemilihan aktivitas menyantuni anak yatim piatu adalah dalam rangka menangkap minat peserta didik tersebut, sehingga pembelajaran akan mendorong kognitif, afektif, psikomotorik, dan emosi mereka. Setelah aktivitas ini dipilih kemudian dirancang langkah kegiatan 
pembelajaran yang sitematis, sehingga terjadi suatu proses pembelajaran.

Terkait dengan aktivitas santuan anak yatim, aktivitas pembelajaran diawali dengan mengajak mengenal tentang keluarga. Dari pembelajaran keluarga ini ini diketahui bahwa ternyata ada beberapa keluarga yang unik, tidak sama pada umumnya keluarga. Dalam artian tanpa ibu, tanpa ayah atau bahkan tanpa keduanya karena wafat salah satunya atau dua-duanya. Ketika di kelas ditemukan ada salah satu teman mereka yang sudah tidak berayah karena wafat. Anak tersebut kemudian dijadikan narasumber untuk menceritakan pengalamannya sebagai testimoni. Anak yatim maju di depan kelas dan menceritakan tentang kehidupannya, apa yang dia rasakan, kenapa orangtuanya wafat, siapa yang membiayai pendidikan, dll. Semua diceritakan anak yatim tersebut dengan bahasa anak-anak dan tidak jarang juga disertai tanya jawab antar mereka.

Berawal dari cerita anak yatim di depan kelas tersebut, kemudian diskusi tentang Yatim dimulai di kelas MI Alam Alfa Kids dan peserta didik sepakat untuk menyantuni anak yatim. Mereka membuat kado masing-masing di madrasah yang isinya $100 \%$ dipilih oleh mereka sendiri dan atas kecenderungan pilihan terbaik mereka. Isi dan bungkus kado adalah cerminan kasih sayang kepada anak Yatim dalam versi anak-anak. Sedangkan orangtua/wali MI Alam Alfa Kids berpartisipasi memberi santunan dalam amplop tertutup, sehingga jumlahnya hanya orangtua/wali yang tahu.

\section{b. Melakukan perjalanan sekolah;}

Setelah aktivitas PAI ditentukan dan peserta didik mendapatkan penjelasan tentang aktivitas tersebut, maka anak bersama guru melakukan perjalanan sekolah pada kondisi yang menjadi pusat aktivitas tersebut. Selama penjalanan sekolah, anak diajak untuk melakukan berbagai pengamatan dan aktivitas pada kondisi sesungguhnya ditempat itu. Pada kondisi inilah keaktifan dan perhatian spontan anak akan muncul, sehingga meningkat interaksi, kebahasaan, dan logika yang terus menerus. 
Dalam hal aktivitas santunan yatim piatu, anak-anak peserta didik MI Alam Alfa Kids berangkat ke sekolah dengan tampak ceria dan membawa kado warna-warni di tangan mereka. Mereka melakukan perjalanan sekolah berbagi ke rumah anak-anak yatim di sekitar sekolah. Sebelum berangkat ditetapkan kesepakatan-kesepakatan selama perjalanan dan apa saja yang akan mereka lakukan di rumah anak yatim. Aktivitas ini memberikan kesan kasih sayang yang nyata, bukan hanya teori tentang kemanusiaan. Peserta didik terasah bukan sekedar otaknya, tetapi juga hati dan emosinya.

\section{c. Pembahasan hasil pengamatan}

Setelah kegiatan perjalanan sekolah berbagai aktivitas yang telah diamati anak kemudian dibicarakan lagi dalam kelas. Dalam suasana interaksi ini dibahas masing- masing hal yang dilihat dan ditemukan anak dari hasil pengamatannya. Guru menjadi fasilitator terhadap alur interaksi diskusi antar peserta didik.

Sehubungan dengan aktivitas santunan yatim piatu tersebut, setelah melakukan perjalanan menyantuni anak yatim ke rumahrumah, peserta didik MI Alam Alfa Kids kembali ke madrasah. Di madrasah bersama guru kemudian diajak mendiskusikan berbagai hal tentang kondisi selama perjalanan. Anak-anak bebas mengutarakan berbagai hal tentang hasil pengamatan mereka dan suasana hati dalam melakukan aktivitas tersebut. Dalam pembahasan ini akhirnya dibahas tentang menemukan arti sebuah keluarga dalam kehidupan. Mereka diajak bersyukur kepada Allah atas nikmat keluarga yang mereka miliki.

\section{d. Menceritakan lingkungan yang diamati}

Langkah berikutnya untuk menanamkan perilaku positip anak pada lingkungan, guru mengajak peserta didik untuk menceritakan berbagai kondisi lingkungan yang diamati. Kondisi tersebut dihubungkan dengan peristiwa atau kondisi lain yang relevan, terutama dengan tindakan dan sikap orang terhadap lingkungan tersebut. Peserta didik melalui bimbingan guru dilatih keberaniannya untuk mempresentasikan hasil pengamatannya secara kreatif. 
Peserta didik MI Alam Alfa Kids dalam aktivitas menyantuni anak yatim pada tahap ini dibimbing oleh guru melakukan presentasi tentang kehidupan anak yatim piatu yang dikunjungi. Presentasi dilakukan secara individu dengan bimbingan guru. Peserta didik juga diajak membandingkan dengan kondisi kehidupan keluarga mereka yang masih utuh. Guru mengajak peserta didik untuk bersyukur kepada Allah akan nikmat keluarga yang Allah berikan kepada mereka.

\section{e. Kegiatan ekspresi}

Sebagai tahapan pembelajaran, agar peserta didik lebih menghayati kondisi lingkungan yang telah diamati, guru menugaskan anak untuk mengekpresikan terhadap hal-hal yang ada pada lingkungan atau hasil dari proses pembelajaran. Diantaranya dengan jalan mewarnai, menggambar, membuat sesuatu, menirukan gerakgerik orang yang diamati melalui berbagai bentuk permainan dan nyanyian.

Pada tahap ini, peserta didik MI Alam Alfa Kids dalam aktivitas menyantuni anak yatim dibimbing oleh guru melakukan ekspresi berupa prakarya membuat bingkai foto dengan gambar keluarga tercintanya. Bingkai foto tersebut dibawa pulang untuk dipersembahkan kepada keluarga di rumah.

Dalam setiap tahapan guru dipandu oleh muatan kurikulum yang ingin dicapai dalam proses pembelajaran PAI. Muatan kurikulum tersebut diretaskan dalam aktivitas tersebut, sehingga peserta didik menjani proses dengan mengalir. Pembelajaran dengan demikian, akan memberikan kesan mendalam dalam diri peserta didik, sehingga jiwa spiritual anak akan terus meningkat.

\section{f. Intepretasi Penelitian}

Pembentukan pribadi muslim yang berupa pengalaman sepenuhnya dari ajaran Islam yang bersumber dari Allah dan Rasul-Nya tidak akan tercapai atau terbina kecuali dengan pengajaran dan pendidikan (Zakiah Daradjat, 1992 : 17-18). 
Pengajaran dan pendidikan dalam hal ini ialah Pendidikan Agama Islam. Pendidikan Agama Islam adalah upaya sadar dan terencana dalam menyiapkan peserta didik untuk mengenal, memahami, menghayati, hingga mengimani ajaran agama Islam, dibarengi dengan tuntunan untuk menghormati penganut agama lain dalam hubungannya dengan kerukunan antar umat beragama hingga terwujud kesatuan dan persatuan bangsa (Abdul Majid \& Dian Andayani, 2006 : 130).

Pendidikan Agama Islam merupakan usaha untuk antara lain: menanamkan rasa cinta kepada Allah dalam hati anak didik, mendidik sedini mungkin agar anak taat kepada perintah Allah dan menjauhi larangan-Nya, membiasakan anak berakhlakul karimah, memberi tauladan dan nasehat yang baik, membentuk anak berbudi luhur dan berpegang teguh pada ajaran Islam dan sebagai warga Negara (Mahmud Yunus, 1983 : 13).

Berdasarkan hal tersebut, PAI merupakan mata pelajaran yang bukan sekedar bersifat pragmatis semata, namun sekaligus bersifat normatif. Atas dasar ini pencapaian pembelajaran PAI bukan sekedar diukur dengan nilai angka di raport dan kemampuan mengerjakan tes kognitif saja, tetapi juga dilihat sejauhmana pengetahuan, sikap, dan keterampilan PAI terejawantah-kan dalam kehidupan sehari-hari. Untuk dapat mewujudkan PAI demikian, peran guru sangat penting untuk mensukseskan proses pendidikan berkualitas.

Guru sebagai pendidik atau pengajar merupakan penentu kesuksesan dalam pendidikan. Oleh sebab itu, guru dituntut untuk mengembangkan kreativitasnya dalam proses belajar mengajar. Guru kreatif selalu mencari cara bagaimana agar proses belajar mencapai hasil sesuai dengan tujuan, serta berupaya menyesuaikan pola-pola tingkah lakunya dalam mengajar dengan tuntutan pencapaian tujuan, dengan mengembangkan faktor situasi kondisi belajar siswa (Cece Wijaya, A. Tabrani Rusyan, 1994 : 189).

Kreativitas ini memungkinkan guru yang bersangkutan menemukan bentuk mengajar yang sesuai, terutama dalam memberi bimbingan, dorongan dan arahan agar siswa dapat belajar secara 
efektif. Berdasarkan deskripsi data dan analisis data tersebut di atas dapat diintepretasikan bahwa pembelajaran PAI berbasis aktivitas kontekstual merupakan upaya kreatif dalam pembelajaran PAI untuk mendekatkan PAI dengan kehidupan yang nyata, sehingga PAI menjadi aplikatif dan implementatif sesuai dengan tuntutan kehidupan. Oleh karena itu, pembelajaran PAI berbasis aktivitas kontekstual dapat disebut sebagai pembelajaran PAI rekonstruktif kontekstual.

\section{Simpulan}

Berdasarkan deskripsi data, analisis data, dan intepretasi data tersebut di muka, maka dapat disimpulkan bahwa pembelajaran PAI berbasis aktivitas kontekstual yaitu pembelajaran PAI rekonstruktif kontekstual, yakni upaya kreatif dalam pembelajaran PAI untuk mendekatkannya dengan kehidupan yang nyata, sehingga PAI menjadi aplikatif dan implementatif sesuai dengan tuntutan kehidupan. Untuk mencapai hal ini diperlukan pemahaman tentang hal-hal sebagai berikut: a) pemahaman makna PAI berbasis aktivitas yang rekonstruktif kontektualis; b) kemampuan memilih jenis aktivitas yang rekonstruktif kontektualis; dan c) daur proses pendidikan yang rekonstruktif kontektualis. 


\section{Daftar Pustaka}

Abdul Majid \& Dian Andayani. 2006. Pendidikan Agama Islam berbasis Kompetensi (Konsep dan Implementasi Kurikulum 2004), Bandung: Remaja Rosdakarya.

Agus Soejiono. 1999. Aliran Baru dalam Pendidikan, Bandung: CV. Ilmu

Cece Wijaya, A. Tabrani Rusyan. 1994. Kemampuan Dasar Guru dalam Proses Belajar Mengajar, Bandung: Remaja Rosda Karya.

Hary Priatna Sanusi. 2013. Peran Guru PAI Dalam Pengembangan Nuansa Religius di Sekolah, dalam Jurnal Pendidikan Agama Islam Ta'lim, Vol. 11 No. 2 Tahun 2013.

Liputan 6, 23 Juli 2013, Jam 15.39 WIB, Mendikbud: IAIN Berubah Jadi UIN, Siapa yang Urus Agama?.

Mahmud Yunus. 1983. Metodik Khusus Pendidikan Agama (Jakarta: Hidayat).

Minnah El Widdah. 2013. Problematika Proses Pembelajaran Pendidikan Agama Islam di Sekolah Menegah Pertama (SMP), dalam jurnal At Ta'lim IAIN Imam Bonjol, Vol. 4.

Muhaimin dan Abdul Mudjieb. 1993. Pemikiran Pendidikan Islam, Bandung: Trigenda Karya.

-------------, 1998, Potret Paradigma Pengembangan Pendidikan Islam di Indonesia, Jurnal STAIN Malang, No. 5.

Sutrisno, Pendidikan Islam Yang Menghidupkan (Studi Kritis Terhadap Pemikiran Pendidikan Fazlur Rahman), tersedia online di http://sutrisno63.blogspot.com/2008/01/prof-sutrisno-pendidikan-islamyang.html, diakses Jumat, 17 Oktober 2014 jam 09.00 WIB

Syamsun Niam. 2013. Institusi Pendidikan dalam Tasawuf, Jurnal Kanz Philishophia Vol. 3 No. 2 Desember.

Tafsir, Ahmad, Filsafat Pendidikan Islam, Bandung: PT. Rosda Karya

Tim Puskur. 2008. Model Pembelajaran Berbasis Alam Pendidikan Anak Usia Dini Formal dan Non Formal, Jakarta: Pusat Kurikulum Badan Penelitian dan Pengembangan Pendidikan Departemen Pendidikan Nasional

Zakiah Daradjat. 1992. Ilmu Pendidikan Agama Islam, Jakarta: Bumi Aksara 